\title{
Molecular aspects of MERS-CoV
}

\author{
Ali A. Rabaan $(\bowtie)^{1}$, Ali M. Bazzi ${ }^{2}$, Shamsah H. Al-Ahmed ${ }^{3}$, Jaffar A. Al-Tawfiq ${ }^{4,5}$ \\ ${ }^{1}$ Molecular Diagnostic Laboratory, Johns Hopkins Aramco Healthcare, Dhahran 31311, Saudi Arabia; ${ }^{2}$ Microbiology Laboratory, Johns \\ Hopkins Aramco Healthcare, Dhahran 31311, Saudi Arabia; ${ }^{3}$ Specialty Paediatric Medicine, Qatif Central Hospital, Qatif 32654, Saudi \\ Arabia; ${ }^{4}$ Specialty Internal Medicine, Johns Hopkins Aramco Healthcare, Dhahran 31311, Saudi Arabia; ${ }^{5}$ Indiana University School of \\ Medicine, Indianapolis, IN 46202, USA
}

(C) Higher Education Press and Springer-Verlag Berlin Heidelberg 2017

\begin{abstract}
Middle East respiratory syndrome coronavirus (MERS-CoV) is a betacoronavirus which can cause acute respiratory distress in humans and is associated with a relatively high mortality rate. Since it was first identified in a patient who died in a Jeddah hospital in 2012, the World Health Organization has been notified of 1735 laboratory-confirmed cases from 27 countries, including 628 deaths. Most cases have occurred in Saudi Arabia. MERS-CoV ancestors may be found in Old World bats of the Vespertilionidae family. After a proposed bat to camel switching event, transmission of MERS-CoV to humans is likely to have been the result of multiple zoonotic transfers from dromedary camels. Human-to-human transmission appears to require close contact with infected persons, with outbreaks mainly occurring in hospital environments. Outbreaks have been associated with inadequate infection prevention and control implementation, resulting in recommendations on basic and more advanced infection prevention and control measures by the World Health Organization, and issuing of government guidelines based on these recommendations in affected countries including Saudi Arabia. Evolutionary changes in the virus, particularly in the viral spike protein which mediates virus-host cell contact may potentially increase transmission of this virus. Efforts are on-going to identify specific evidence-based therapies or vaccines. The broad-spectrum antiviral nitazoxanide has been shown to have in vitro activity against MERS-CoV. Synthetic peptides and candidate vaccines based on regions of the spike protein have shown promise in rodent and non-human primate models. GLS-5300, a prophylactic DNA-plasmid vaccine encoding $S$ protein, is the first MERS-CoV vaccine to be tested in humans, while monoclonal antibody, $\mathbf{m 3 3 6}$ has given promising results in animal models and has potential for use in outbreak situations.
\end{abstract}

Keywords MERS-CoV; Saudi Arabia; spike protein; transmission; evolution; vaccine

\section{MERS-CoV overview}

Middle East respiratory syndrome coronavirus (MERS$\mathrm{CoV})$ is a betacoronavirus which can cause acute respiratory illness in humans [1]. Like other coronaviruses, including the severe acute respiratory syndrome (SARS)$\mathrm{CoV}$, it is a positive strand RNA virus. It has a genome of over 30000 nucleotides, containing seven predicted open reading frames (ORFs) and four structural genes for spike $(\mathrm{S})$, nucleocapsid $(\mathrm{N})$, membrane $(\mathrm{M})$, and envelope $(\mathrm{E})$ proteins [2-6]. The $\mathrm{S}$ protein has been implicated in crossspecies MERS-CoV transmission and host cell infection [6].

Received August 16, 2016; accepted January 23, 2017

Correspondence: ali.rabaan@jhah.com; arabaan@gmail.com
MERS-CoV infection was first observed in Saudi Arabia in a 60-year-old man who died on June 24, 2012, after presenting at a Jeddah hospital on June 13, 2012 with acute pneumonia and subsequent renal failure [7]. The first human cluster was retrospectively confirmed in a public hospital in Jordan in April 2012, when 11 people became ill [8]. To date, WHO has been notified of 1735 laboratoryconfirmed cases from 27 countries, and of 628 deaths, mostly in Saudi Arabia, and has reported an overall case fatality rate of $36 \%$ [9].

In MERS-CoV infection, acute viral pneumonia is often present, while gastrointestinal symptoms may also be experienced. Clinical severity can vary from asymptomatic to death, usually from acute respiratory distress syndrome (ARDS) [9-13]. Comorbid illness, older age, and high viral load have been associated with poor outcomes $[10,11,13]$. ICU admission linked to MERS-CoV infection 
has been associated with a mortality rate of $74.2 \%$ in a hospital in Saudi Arabia [14].

Emergence of human MERS-CoV probably resulted from multiple zoonotic crossovers, mainly from dromedary camels, however, limited human-to-human transmission has been observed, for example, in healthcare facilityassociated outbreaks in Saudi Arabia, Korea, and United Arab Emirates (UAE) [5,15-20]. These were attributed to inadequacies in infection prevention and control procedures.

The following review of the molecular aspects of MERS-CoV considers evolution, transmission, genomics, possible mutations, and potential vaccine/therapeutic targets.

\section{MERS-CoV evolution}

Coronaviridae is a family of viruses which can adapt to multiple species, including humans. Bats are considered to be the main mammalian CoVs reservoir [21]. Human coronaviruses (HCoVs) comprise Alphacoronavirus and Betacoronavirus genera; MERS-CoV is a betacoronavirus [22]. Betacoronaviruses are further subdivided into four clades, a to d; MERS-CoV falls into clade c (lineage 3) [23]. Closest known coronavirus relatives to MERS-CoV include the prototypic clade c betacoronaviruses, Tylonycteris bat virus HKU4 and Pipistrellus bat HKU5 virus [7,22-30]. Another more closely related virus, termed $\mathrm{PML} / 2011$ and later $\mathrm{NeoCoV}$, was isolated from a Neoromicia zuluensis bat in South Africa. This strengthens the possibility that ancestors of MERS-CoV may be found in Old World bats of the Vespertilionidae family, which includes the Neoromicia and Pipistrellus genera [30,31]. The most recent common ancestor of MERS-CoV and $\mathrm{NeoCoV}$ was estimated at approximately 44 years ago [32].

Rooting of the phylogenetic tree of MERS-CoV to $\mathrm{NeoCoV}$ suggests that MERS-CoV evolution occurred in camels prior to that in humans, with the initial bat-to-camel host switching event occurring in Africa [30]. Current theory suggests that an exchange of genetic elements among ancestral viruses led to MERS-CoV emergence; this may have occurred in bats, or else camels may have acted as a genetic "mixing vessel" [30]. Molecular clock dating suggests that for human isolates the evolutionary rate for epidemiologically unlinked MERS-CoV genomes is $1.12 \times 10^{-3}$ substitutions per site per year, and time to most recent common ancestor (tMRCA) is March 2012 [33]. Meanwhile a cluster of isolates identified in the eastern part of the Arabian Peninsula are estimated to have diverged toward the end of 2012 [34]. For all MERS-CoV isolates, including human and camel, tMRCA has been estimated in late 2010 [32]. Twenty eight potential recombination sequences have been identified in the
MERS-CoV genome and frequent transmission to and fro between humans and camels has been observed since the initial transmission event [7].

\section{MERS-CoV transmission}

Multiple zoonotic transfers are considered to have caused most human MERS-CoV infections, with limited secondary human-to-human transmission, particularly in family and healthcare settings, resulting in hospital-associated outbreaks in Saudi Arabia, Korea, and UAE [5,1520,35,36]. Human-to-human transmission appears to require close contact, however, adaptations in host-virus transmission determinants may increase vulnerability to both cross-species and human-to-human transmission [1]. Mutations in the $\mathrm{S}$ protein, particularly the receptor binding domain (RBD), would be important in alteration in MERS-CoV transmission properties, similar to observations in other betacoronaviruses [37-41]. Human dipeptidyl peptidase 4 (DPP4; CD26) is a functional MERS-CoV receptor, with binding mediated by $\mathrm{S}$ protein $[39,40]$. $\mathrm{S}$ protein is the main neutralizing antibody target during coronavirus infections [42]. The MERS-CoV S has also been implicated in cross-species transmission. Recent evolutionary analysis suggested that the $\mathrm{S}$ protein was under strong positive selection pressures during zoonotic transmission of MERS-CoV to humans [7]. Out of nine positive selection sites in the $\mathrm{S}$ protein, six were found in the RBD.

Camels are a likely major zoonotic source for human infection. MERS-CoV antibodies have been detected in the majority of dromedary camels tested in the Arabian Peninsula and parts of Africa, including Egypt, Oman, Jordan, Qatar, Saudi Arabia, Ethiopia, Tunisia, Kenya, and Nigeria $[33,34,43-48]$. MERS-CoV has not been identified in other animals such as sheep, goats, cows, or water buffalo, although one recent study suggests alpaca may be another viral reservoir $[35,49]$. Emergence of the virus in this New World camelid presents a potential widening of the zoonotic MERS-CoV range to South America and the United States, and other areas where alpacas are farmed [49]. Meanwhile bats are considered to be the main mammalian reservoir for MERS-CoV [21].

There is a potential risk of transmission from food products derived from dromedary camels [48]. However, despite high frequency of consumption of dromedary camel milk and meat in the countries of the Arabian Peninsula, and the ritual significance of these camels after the Hajj pilgrimage, the frequency of MERS-CoV infection is substantially lower than that of these practices [5]. There is currently no evidence to suggest increased transmission of MERS-CoV among Hajj pilgrims despite the increased circulation of other respiratory pathogens [50-53]. The extent of the human populations at risk from 
occupational exposure to dromedaries in the Middle East and Africa may be under-estimated, as direct contact rather than ingestion of dromedary camel products may be the more significant risk factor $[5,44,54,55]$. There is genetic evidence for direct contact transmission of MERS-CoV from dromedary camels to humans. For example, in one case of a MERS-CoV patient in Jeddah who had been caring for a MERS-CoV-carrying dromedary camel, the genome sequences from the man and the camel shared a unique single nucleotide polymorphism (SNP) signature [56,57].

Factors such as sample type or test employed may impact on likelihood of detection of human MERS-CoV infection. WHO recommends sampling from the lower respiratory tract (LRT) for real time RT-PCR testing, the gold standard detection method $[5,58]$. However, in most studies upper respiratory tract (URT) samples are used, due mainly to convenience and non-invasiveness $[5,58]$. Serological testing methods are also available, including those based on ELISA or immunofluorescence (IFA), traditional microneutralization tests (MNT), and pseudo particle neutralisation tests (ppNT) [5,35,59-61]. Further testing and validation of these tests in the context of mild or asymptomatic disease should help in development of accurate assessments of transmission and fine-tuning of public health policy [5]. More extensive and strategic serosurveys among the human population are needed to understand the extent of levels of MERS-CoV infection, in particular in the absence of severe symptoms [59-61]. The reason for lack of reported MERS-CoV infection in humans in Africa is not known, despite confirmed zoonotic potential of camel-carried viruses [33,35,43]. Studies on transmission among camels show evidence of circulation across broad areas including Nigeria, Tunisia, Ethiopia, and Kenya $[33,62]$. In one recent study in Kenya, use of serological tests indicated an apparent absence of human MERS-CoV infections, suggesting that there are unrecorded cases of human MERS-CoV similar to previous reports in Saudi Arabia [63,64]. There may also be less virulent strains in circulation in Africa, or different types of individuals may be more commonly exposed [63]. Extensive screening would help guard against under- or over-estimation of transmission or mortality rate [5,54].

Human-to-human transmission in healthcare settings has been linked to lack of or breakdown in infection control and prevention procedures, and can be successfully limited by aggressive implementation of effective measures $[4,65,66]$. Outside the Middle East, infection has been spread by travelers from the Middle East, including the outbreak in South Korea in 2015 [67], as well as cases in the UK [68], the United States [69], the Netherlands [70], and Thailand [71]. The first human case of MERS-CoV infection imported into China in 2015 arose in a South Korean contact of confirmed MERS-CoV cases in the South Korean outbreak [72]. The emergence of
MERS-CoV in second and third generation contacts in that outbreak raised concerns that the virus could be mutating to become more readily transmissible between humans.

To limit healthcare facility-associated human-to-human transmission, WHO have issued detailed infection prevention and control guidelines for dealing with suspected or confirmed cases of MERS-CoV [1]. These include both standard and more advanced precautions for caring for patients with acute respiratory infections, as well as ongoing training and education of healthcare workers. In hospital outbreaks in Saudi Arabia, WHO identified contributory issues including emergency department waiting room overcrowding and inadequate basic infection prevention and control procedures [17]. Tackling such deficiencies led to a decline in cases in both Saudi Arabia and Korea. Guidelines have been issued in these countries, in line with WHO recommendations $[4,65,66]$.

\section{Genomics and phylogenetic studies}

Full understanding of the transmission of MERS-CoV depends on the underlying viral genetics. Whole-genome deep sequencing of 32 complete or partial MERS-CoV genomes from respiratory samples from human MERS$\mathrm{CoV}$ cases in Saudi Arabia was carried out to help determine evolution of the virus in Saudi Arabia and surrounding areas [3]. Phylogenetic analysis of the sequences alongside 33 previously available sequences indicated that there were four Saudi Arabia clades, of which only the Hafr-Al-Batin clade was contributing to current cases [2,3]. Clade disappearance could indicate increasing success of improved surveillance and infection prevention and control measures, and a viral $\mathrm{R}_{0}$ of less than 1 , however, undiagnosed asymptomatic spread could also be a factor [3]. Genomic and phylogenetic analysis suggested that a uniform evolutionary gradient of MERS-CoV across Saudi Arabia and surrounding countries was unlikely, and that transmission was probably due to movement of infected animals, animal products, or infected humans $[2,3,72,73]$.

Overall, the 182 MERS-CoV genomes sequenced to date from humans and camels share greater than $99 \%$ overall identity [74]. However, some variation is evident between viral genomes from camels in Africa and those from both humans and camels in the Arabian Peninsula $[43,75]$. Results of genomic and phylogenetic analyses suggest that MERS-CoV viruses fall mainly into two clades, A and B, with MERS-CoV viruses from dromedary camels in Egypt falling into a distinct cluster termed clade C, separate from MERS CoVs detected elsewhere (Fig. 1) $[3,6,72,76,77]$. Fig. 1 adapted from the study by Zhang et al. (2016) shows the phylogenetic tree of human and camel MERS-CoV strains, constructed by the maximumlikelihood method and rooted on the Egyptian dromedary sequence (clade C) [6]. Most strains fall into clade B, 
which contains five groups comprising both human- and camel-derived viral sequences from different regions (Fig. 1). Group I includes 2014 camel and human sequences from the United Arab Emirates (UAE), 2013 camel sequences from Saudi Arabia and 2013 human sequences mainly from Qatar and France, with one from Saudi Arabia. Group II contains 2013 human sequences from Saudi Arabia and the UK. Group III includes the ChinaGD01 strain as well as South Korean and Saudi Arabian strains from 2015. Group IV is a small group (two sequences) of 2012 human-derived Saudi Arabia strains. Finally Group V is the largest group, dominated by human Saudi Arabia strains from 2014 and 2015, along with an assortment of other human-derived strains including 2012 strains from Jordan, the UK, and Saudi Arabia, 2014 strains from the USA and Qatar, and one 2013 strain from UAE, as well as two 2013 camel strains from Saudi Arabia (Fig. 1) [6,72].

Phylogenetic analyses suggest that recombination has occurred between members of different clade B groups. Nucleotides 1-23722 and nucleotides 23723 to 30126 of MERS-CoV appear to have independent molecular clock rates $[72,78]$. In one study, 28 potential recombination events were identified, including in three camel MERS$\mathrm{CoVs}$ and 25 human MERS-CoVs from different clade B groups [6]. Genomic and phylogenetic analysis indicated that the S protein codon 1020, in the membrane fusion activity-related heptad repeat 1 (HR1) region, was under episodic selection pressure, while there was more modest positive selection of S codon 509, beside the S-protein/ DPP4 binding interface [3]. Thus while MERS-CoV is not yet considered capable of a high and sustained human-tohuman transmission rate, possible changes should be monitored in the S-protein, especially as it has been previously implicated in expansion of viral host range in other viruses including SARS-CoV $[37,79,80]$.

Thus, genomic studies indicate that there may be multiple recombination events in MERS-CoV and that the $\mathrm{S}$ gene is an area of particular note. Keeping track of mutations arising in MERS-CoV is vital in detecting changes that may increase human-to-human or animalhuman transmission and in developing therapies and vaccines.

\section{Potentially important mutations}

The major concern is that mutations may arise in MERS$\mathrm{CoV}$ which would increase viral affinity for human host cells. Coronaviruses gain entry into host cells by using the $\mathrm{S} 1$ subunit of the $\mathrm{S}$ protein to bind a host cell receptor such as DPP4, then use the S2 subunit for membrane fusion, with cleavage of the spike at the S1/S2 boundary by host proteases [41,81] (Fig. 2). Fig.2, from the study by Durai et al. (2015), shows the replication cycle of MERS-CoV, including S protein-DPP4 binding [81]. This cleavage divides the spike into the N-terminal S1 subunit, containing the $\mathrm{RBD}$, and the $\mathrm{C}$-terminal $\mathrm{S} 2$ subunit, containing the fusion peptide, the HR1 and HR2 domains, and the transmembrane (TM) domain (Fig. 2) [37,81]. Membrane fusion also requires conformational rearrangement of S2, exposing the fusion peptide and causing formation of a sixhelix bundle (6HB) of which HR1 and HR2 are essential elements [37].

MERS-CoV can enter human cells, whereas the bat HKU4 virus cannot. Mutational manipulation of the SI/S2 boundary of the HKU4 virus $\mathrm{S}$ protein showed that two single mutations, S746R and N762A, enabled it to enter human cells [41]. As the MERS-CoV spike contains these mutations, it is likely that they are critical in the ability of MERS-CoV to infect human cells and that mutations in this region of the MERS-CoV S protein would be of particular interest in enhancing transmissibility [41]. However, it was recently unexpectedly shown that MERS-CoV with mutant S proteins with reduced affinity for DPP4 arose during the 2015 South Korea outbreak [82]. The detected point mutations I529T or D510G both reduced RBD/DPP4 affinity [82]. A pseudotyped I529T mutation-bearing virus also had reduced host cell entry. Thus MERS-CoV adaptation in this outbreak appears to have been driven by host immunological pressure, ultimately leading to reduced rather than increased virushost affinity [82].

The importance of the HR1 and HR2 regions in evolution of the $\mathrm{S}$ gene in betacoronavirus evolution was confirmed in a recent study showing that there were many positively selected sites in this region, including R652 and V1060, which were associated with expansion of host range [83]. In recent MERS-CoV evolution, adaptive HR1 mutations at position $1020(\mathrm{Q} / \mathrm{R} / \mathrm{H} 1020)$ in camels or a previous host, which mildly reduced HR1 and HR2mediated helical stability and bundle formation, have been implicated in spread to humans [83]. While it may seem surprising that moderately destabilizing mutations were positively selected, these types of mutations can increase in vitro infection efficiency [83].

Following entry into host cells, MERS-CoV nonstructural polyproteins ppla and pplab are made, then cleaved by two viral proteases, the main protease (Mpro) and the papain-like protease (Fig. 2) [81,83]. Cleavage of ppla and pplab is essential in viral maturation. The MERS-CoV Mpro crystal structure was recently described and shown to be similar to other coronavirus Mpro proteases [84]. Also like other Mpro proteases, dimerization is essential for catalysis. Mutational analysis showed that mutation M298R at the dimerization interface yielded a more stable dimer with greater proteolytic activity, suggesting potential importance of mutations that could arise in viral proteins other than the $\mathrm{S}$ protein [84]. 


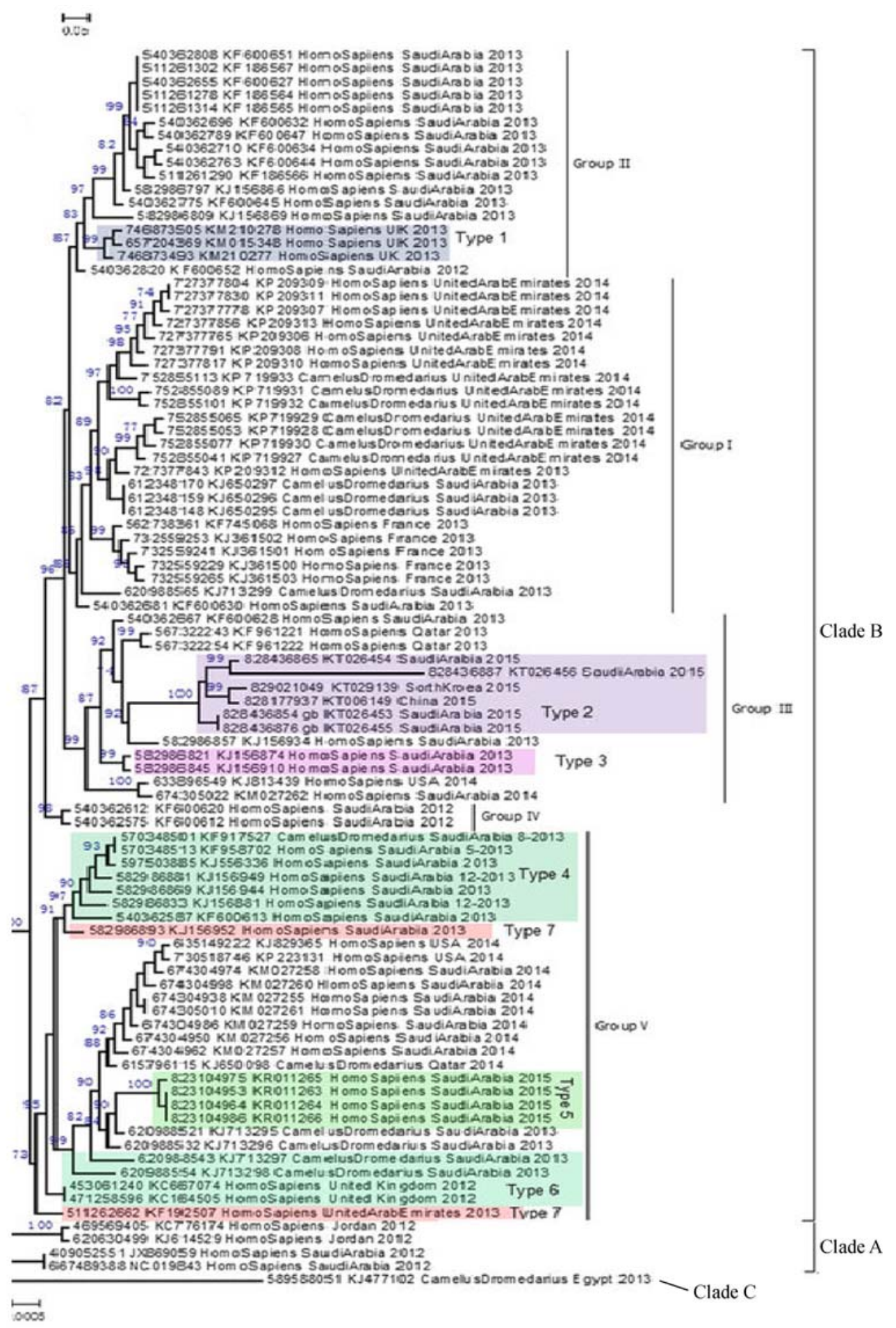

Fig. 1 Phylogenetic tree of human and camel MERS-CoV. Adapted from: Zhang et al., 2016, Evolutionary dynamics of MERS-CoV: potential recombination, positive selection and transmission; available from: http://www.nature.com/articles/srep25049; licensed under a Creative Commons Attribution 4.0 International License: https://creativecommons.org/licenses/by/4.0/.

\section{Therapies and vaccines}

There is currently no specific evidence-based therapy or vaccine for MERS-CoV. Combined antiviral therapies have been used in patients who develop respiratory illness, for example, pegylated interferon (IFN)- $\alpha$, ribavirin, and/ or lopinavir/ritonavir $[85,86]$. Potential efficacy against MERS-CoV has been suggested by in vitro and animal 


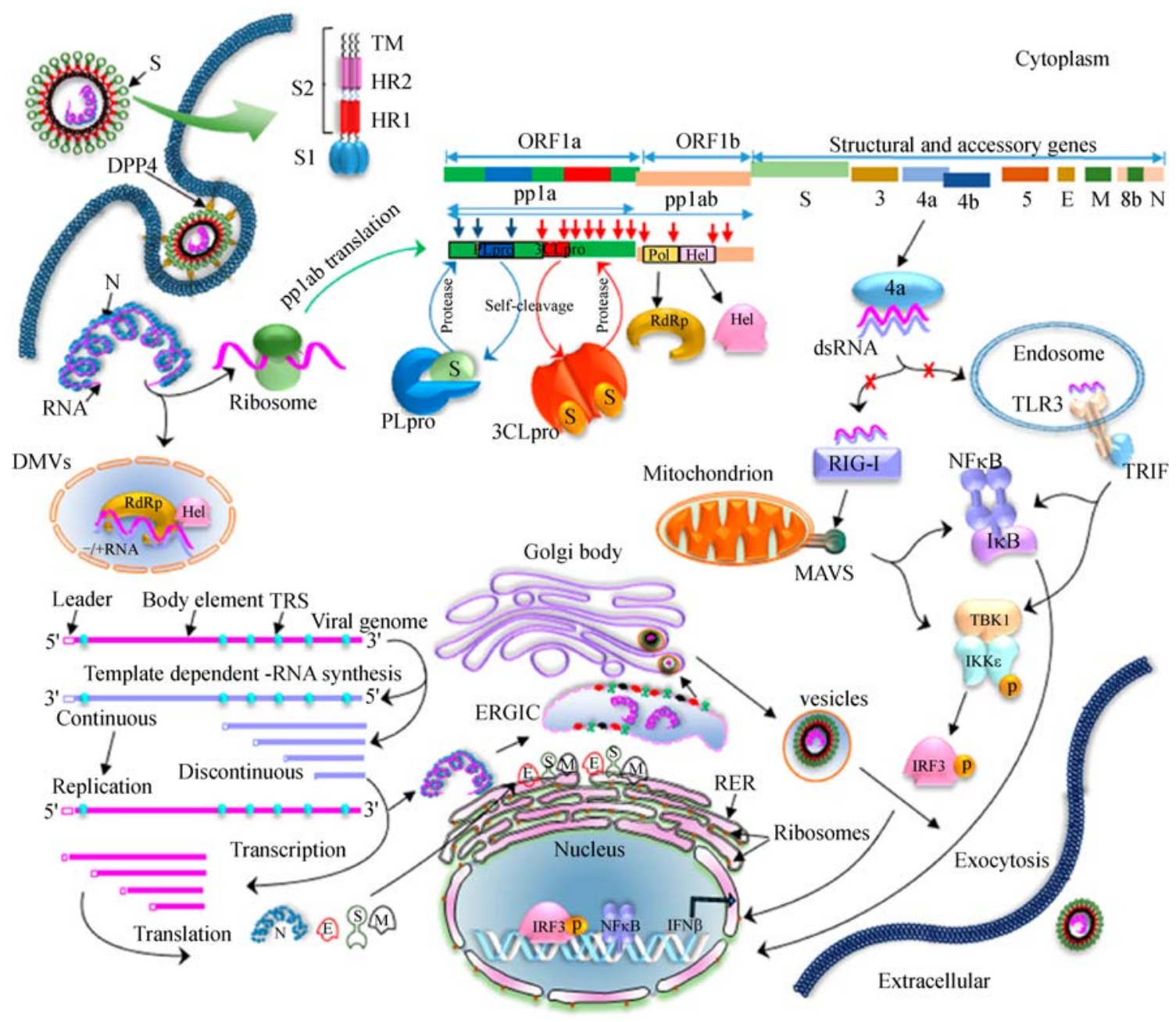

Fig. 2 Replication cycle of MERS-CoV. From: Durai et al., 2015, Middle East respiratory syndrome coronavirus: transmission, virology and therapeutic targeting to aid in outbreak control; available from: http://www.nature.com/emm/journal/v47/n8/full/emm201576a.html; licensed under a Creative Commons Attribution 4.0 International License: https://creativecommons.org/licenses/by/4.0/legalcode.

studies, however, in vivo efficacy is less well-established [85-88]. Recently the broad-spectrum antiviral nitazoxanide has been shown to have in vitro activity against MERS-CoV and other coronaviruses, and has been suggested to be a possible MERS-CoV therapeutic candidate [89]. However, development of a targeted antiMERS-CoV therapy would be an attractive option.

The importance of the HR regions of the MERS-CoV S protein in adaptive evolution suggests that they would be potentially effective targets for antiviral synthetic peptides [83]. Effectiveness of a peptide named HR2P, spanning 1251-1286 of HR2 domains, has been demonstrated in vitro, with effective inhibition of viral replication and $\mathrm{S}$ protein mediated cell fusion [90]. Effectiveness of peptides that interfere with HR-mediated $6 \mathrm{HB}$ bundle formation has also been shown for other viruses including SARS-CoV [91,92]. A HR2P analog termed HR2P-M2 was recently shown to be even more effective in blocking $\mathrm{S}$ proteinmediated cell-cell fusion in vitro and in inhibition of MERS CoV-expressing pseudovirus infection [93]. It could interact with a HR1 peptide to effectively block $6 \mathrm{HB}$ bundle formation. When administered intranasally to ad-5-human DPP4-transduced mice, it protected the animals from MERS-CoV infection, with lung viral titers being decreased more than 1000-fold. Protection was enhanced by combination with interferon $\beta$ [93].

Another potential MERS-CoV-specific drug target is the papain-like protease $\left(\mathrm{PL}^{\mathrm{pro}}\right)$, which is involved in release of NSPs 1, 2, and 3 from polyproteins $1 \mathrm{a}$ and $1 \mathrm{ab}$ in coronaviruses [94]. The X-ray 3-D crystal structure of the MERS-CoV PL ${ }^{\text {pro }}$ was shown to be similar to the equivalent SARS-CoV enzyme, comprising ubiquitin-like and catalytic core domains [94]. However, unique aspects of the MERS-CoV PL ${ }^{\text {pro }}$ crystal structure, including the 
oxyanion hole, and S3 and S5 subsites, suggest potential targets for specifically designed antivirals [94].

Development of a MERS-CoV vaccine would be a major step forward in stopping spread of this virus. In a study on viral shedding and antibody response on 37 adult MERS-CoV patients, all patients who survived infection produced anti-MERS-CoV IgG and neutralizing antibodies, compared to only about half of those who died [95]. However, antibody levels were only weakly inversely correlated with LRT viral load and were insufficient to eliminate LRT virus [95]. Given this apparent inadequacy of adaptive immune responses to clear MERS-CoV, the relatively high mortality rate, and the potential for the virus to recombine and adapt to be more readily transmissible, it is important that vaccine development be prioritised. Results of one study using ppNT on a representative range of serum samples suggested that all currently circulating human MERS-CoV strains are of one serotype, thus prototype strain selection is unlikely to be a major factor in success of vaccine candidates [96]. However, virus isolation success from respiratory samples correlated with IgA antibody levels, suggesting that vaccine formulations should be evaluated for IgA production potential [96].

Unsurprisingly the S protein has been the focus of many candidate vaccines [97-101]. An RBD fragment fused to the Fc portion of human IgG could bind human DPP4 and inhibit MERS-CoV infection in an in vitro cell culture model, and induce a humoral response in vaccinated mice, preventing RBD binding to DPP4 and inhibiting MERS$\mathrm{CoV}$ infection [97]. Intranasal administration induced superior systemic humoral and cellular immune responses than subcutaneous injection [99]. Immunisation of rhesus macaques with an rRBD vaccine resulted in effective and sustained immune responses to MERS-CoV infection 14 days post-vaccination, including production of neutralising antibodies, alleviation of pneumonia, and reduction of viral load in the respiratory tract, further supporting the potential of RBD for use in human vaccines [102]. However, it is possible that vaccines based on RBD or on the S1 subunit may have limited epitope scope, so use of full-length $\mathrm{S}$ protein may be preferable for a broader antibody response [100]. Immunisation of mice and rhesus macaques with DNA expression vectors expressing full-length S protein, then with $\mathrm{S} 1$ subunit protein resulted in robust expression of MERS-CoV neutralising antibodies and protection against MERS-CoV-induced pneumonia [100]. Difficulties in achieving abundant expression and stability of fulllength $\mathrm{S}$ protein have also been addressed by construction of $\mathrm{S}$ protein nanoparticles in combination with Alum or Matrix M1 adjuvant, which induce anti-MERS-CoV neutralizing antibodies in mice [103].

Use of live-attenuated virus-based vaccines or replication-competent viral vectors could be a risky option, given the relative vulnerability of older patients and those with co-morbid diseases such as diabetes [42]. One possible alternative option is use of replication-deficient vectors. Examples of possible vectors which have been successfully used to express MERS-CoV S protein and induce neutralizing antibodies in mice include modified vaccinia virus Ankara (MVA) [104,105] and ad5 or ad41-type adenoviruses [106,107].

Meanwhile, GLS-5300, a DNA-plasmid vaccine encoding MERS-CoV S protein and co-developed by Inovio, GeneOne Life Science Inc. and the Walter Reed Army Institute of Research, has become the first potential MERS$\mathrm{CoV}$ vaccine to be tested in humans [108]. It has entered a phase I clinical trial in healthy volunteers to evaluate its safety and its ability to generate humoral and cellular immune responses over a one-year period [108]. In preclinical trials in mice, camels, and macaques, the vaccine was shown to induce robust immune responses which were effective in preventing viral infection [109]. Given the status of camels as a likely host reservoir, the results from camels were particularly significant [109].

While GLS-5300 and other types of vaccines mentioned above would be intended for prophylactic use, current relatively low incidence of MERS-CoV infection and the lack of reliable small animal models means that both definition of a target population for mass prophylactic vaccination and sufficient demonstration of vaccine efficacy are challenging issues [42]. Thus, development of monoclonal antibodies for use in outbreak situations would be advantageous. Pre-clinical studies of several monoclonal antibodies, mainly targeted against the $\mathrm{S}$ protein, are on-going, some of which have been shown to be protective in animal models, both prophylactically and post-exposure [110-114]. Analysis of one potent monoclonal antibody, m336, which precisely targets the S protein RBD revealed a very low level of somatic mutation in the antibody heavy chain, and that $\mathrm{V}(\mathrm{D}) \mathrm{J}$ recombination and allele-specific residues were critical in generation of high-affinity binding between antibody and RBD [114].

\section{Summary and perspectives}

Thus far, spread of MERS-CoV among humans has been relatively limited, with Saudi Arabia experiencing the majority of cases. Human infection is likely to have arisen from multiple zoonotic transfer events, most likely from dromedary camels. There is some debate on the importance of dromedary camels as the most important reservoir of infection, given the preponderance of the virus among camels throughout Africa but relatively low reported levels of human infections, however, the extent of human infections may be under-estimated. Human-to-human transmission appears to require relatively close contact, and outbreaks have been mainly associated with spread within healthcare institutions, connected to inadequate 
infection control and prevention procedures. While genomic and phylogenetic analysis suggests that MERS$\mathrm{CoV}$ is not currently capable of a high and sustained human-to-human transmission rate, it also indicates that mutations, for example, in the viral S-protein, could arise that would increase the viral host range and transmissibility. The relatively high mortality rate associated with the virus points up the importance of continuing to monitor the evolution of the virus and to seek targeted therapies and/or vaccines, bearing in mind the challenges inherent in identifying a relevant target population for vaccination. Promising therapies based on S-protein HR-targeted peptides, as well as potential vaccines based on S-protein nanoparticles are emerging, while a DNA-plasmid vaccine encoding MERS-CoV S protein has entered phase I clinical trials. Continuing to trace the evolution of the virus will be important in predicting possible increases in transmission to and among humans. Implementation of extensive, validated and strategic sero-surveys is vital for a full understanding of the true levels of human infection with MERS-CoV, in particular in the absence of severe symptoms or where symptoms are absent. Meanwhile, aggressive implementation of infection prevention and control procedures in healthcare institutions, careful monitoring of contacts of infected patients and tracing possible sources of infection, for example, occupational contact with dromedary camels, appear to be the most effective ways of keeping control of the transmission of this dangerous virus.

\section{Compliance with ethics guidelines}

Ali A. Rabaan, Ali M. Bazzi, Shamsah H. Al-Ahmed, and Jaffar A. Al-Tawfiq declares that they have no conflict of interest. This manuscript is a review article and does not involve a research protocol requiring approval by the relevant institutional review board or ethics committee.

\section{References}

1. World Health Organization (WHO). Middle East respiratory syndrome coronavirus (MERS-CoV): Summary of Current Situation, Literature Update and Risk Assessment. July 7, 2015. Available from http://www.who.int/csr/disease/coronavirus_infections/risk-assessment-7july2015/en/ (Accessed June 8, 2016)

2. Cotten M, Watson SJ, Kellam P, Al-Rabeeah AA, Makhdoom HQ, Assiri A, Al-Tawfiq JA, Alhakeem RF, Madani H, AlRabiah FA, Al Hajjar S, Al-nassir WN, Albarrak A, Flemban H, Balkhy HH, Alsubaie S, Palser AL, Gall A, Bashford-Rogers R, Rambaut A, Zumla AI, Memish ZA. Transmission and evolution of the Middle East respiratory syndrome coronavirus in Saudi Arabia: a descriptive genomic study. Lancet 2013; 382(9909): 1993-2002

3. Cotten M, Watson SJ, Zumla AI, Makhdoom HQ, Palser AL, Ong SH, Al Rabeeah AA, Alhakeem RF, Assiri A, Al-Tawfiq JA,
Albarrak A, Barry M, Shibl A, Alrabiah FA, Hajjar S, Balkhy HH, Flemban H, Rambaut A, Kellam P, Memish ZA. Spread, circulation, and evolution of the Middle East respiratory syndrome coronavirus. MBio 2014; 5(1): e01062-e13

4. Kim JY, Song JY, Yoon YK, Choi SH, Song YG, Kim SR, Son HJ, Jeong SY, Choi JH, Kim KM, Yoon HJ, Choi JY, Kim TH, Choi YH, Kim HB, Yoon JH, Lee J, Eom JS, Lee SO, Oh WS, Choi JH, Yoo JH, Kim WJ, Cheong HJ. Middle East respiratory syndrome infection control and prevention guideline for healthcare facilities. Infect Chemother 2015; 47(4): 278-302

5. Mackay IM, Arden KE. MERS coronavirus: diagnostics, epidemiology and transmission. Virol J 2015; 12(1): 222

6. Zhang Z, Shen L, Gu X. Evolutionary dynamics of MERS-CoV: potential recombination, positive selection and transmission. Sci Rep 2016; 6: 25049

7. Zaki AM, van Boheemen S, Bestebroer TM, Osterhaus AD, Fouchier RA. Isolation of a novel coronavirus from a man with pneumonia in Saudi Arabia. N Engl J Med 2012; 367(19): 18141820

8. Hijawi B, Abdallat M, Sayaydeh A, Alqasrawi S, Haddadin A, Jaarour N, Alsheikh S, Alsanouri T. Novel coronavirus infections in Jordan, April 2012: epidemiological findings from a retrospective investigation. East Mediterr Health J 2013; 19(Suppl 1): S12-S18

9. World Health Organization (WHO). Middle East respiratory syndrome coronavirus (MERS-CoV). 2016. Available from http://www.who.int/emergencies/mers-cov/en/ (Accessed June 10, 2016)

10. Assiri A, Al-Tawfiq JA, Al-Rabeeah AA, Al-Rabiah FA, Al-Hajjar S, Al-Barrak A, Flemban H, Al-Nassir WN, Balkhy HH, AlHakeem RF, Makhdoom HQ, Zumla AI, Memish ZA. Epidemiological, demographic, and clinical characteristics of 47 cases of Middle East respiratory syndrome coronavirus disease from Saudi Arabia: a descriptive study. Lancet Infect Dis 2013; 13(9): 752761

11. Memish ZA, Zumla AI, Al-Hakeem RF, Al-Rabeeah AA, Stephens GM. Family cluster of Middle East respiratory syndrome coronavirus infections. N Engl J Med 2013; 368(26): 2487-2494

12. Min CK, Cheon S, Ha NY, Sohn KM, Kim Y, Aigerim A, Shin HM, Choi JY, Inn KS, Kim JH, Moon JY, Choi MS, Cho NH, Kim YS. Comparative and kinetic analysis of viral shedding and immunological responses in MERS patients representing a broad spectrum of disease severity. Sci Rep 2016; 6: 25359

13. Oboho IK, Tomczyk SM, Al-Asmari AM, Banjar AA, Al-Mugti H, Aloraini MS, Alkhaldi KZ, Almohammadi EL, Alraddadi BM, Gerber SI, Swerdlow DL, Watson JT, Madani TA. 2014 MERSCoV outbreak in Jeddah - a link to health care facilities. N Engl J Med 2015; 372(9): 846-854

14. Almekhlafi GA, Albarrak MM, Mandourah Y, Hassan S, Alwan A, Abudayah A, Altayyar S, Mustafa M, Aldaghestani T, Alghamedi A, Talag A, Malik MK, Omrani AS, Sakr Y. Presentation and outcome of Middle East respiratory syndrome in Saudi intensive care unit patients. Crit Care 2016; 20(1): 123

15. Al-Hameed F, Wahla AS, Siddiqui S, Ghabashi A, Al-Shomrani M, Al-Thaqafi A, Tashkandi Y. Characteristics and outcomes of Middle East respiratory syndrome coronavirus patients admitted to an intensive care unit in Jeddah, Saudi Arabia. J Intensive Care 
Med 2016; 31(5): 344-348

16. Balkhy HH, Perl TM, Arabi YM. Preventing healthcare-associated transmission of the Middle East respiratory syndrome (MERS): our Achilles heel. J Infect Public Health 2016; 9(3): 208-212

17. Brown C. Call for infection control to stem MERS. CMAJ 2014; 186(10): E349

18. Hunter JC, Nguyen D, Aden B, Al Bandar Z, Al Dhaheri W, Abu Elkheir K, Khudair A, Al Mulla M, El Saleh F, Imambaccus H, Al Kaabi N, Sheikh FA, Sasse J, Turner A, Abdel Wareth L, Weber S, Al Ameri A, Abu Amer W, Alami NN, Bunga S, Haynes LM, Hall AJ, Kallen AJ, Kuhar D, Pham H, Pringle K, Tong S, Whitaker BL, Gerber SI, Al Hosani FI. Transmission of Middle East respiratory syndrome coronavirus infections in healthcare settings, Abu Dhabi. Emerg Infect Dis 2016; 22(4): 647-656

19. Madani TA, Althaqafi AO, Alraddadi BM. Infection prevention and control guidelines for patients with Middle East Respiratory syndrome coronavirus (MERS-CoV) infection. Saudi Med J 2014; 35(8): 897-913

20. Zumla A, Hui DS. Infection control and MERS-CoV in health-care workers. Lancet 2014; 383(9932): 1869-1871

21. Drexler JF, Corman VM, Drosten C. Ecology, evolution and classification of bat coronaviruses in the aftermath of SARS. Antiviral Res 2014; 101: 45-56

22. van Boheemen S, de Graaf M, Lauber C, Bestebroer TM, Raj VS, Zaki AM, Osterhaus AD, Haagmans BL, Gorbalenya AE, Snijder EJ, Fouchier RA. Genomic characterization of a newly discovered coronavirus associated with acute respiratory distress syndrome in humans. MBio 2012; 3(6): e00473-e12

23. de Groot RJ, Baker SC, Baric R, Enjuanes L, Gorbalenya AE, Holmes KV, Perlman S, Poon L, Rottier PJM, Talbot PJ, Woo PCY, Ziebuhr J. Family Coronaviridae. In: King AMQ, Adams MJ, Carstens EB, Lefkowitz EJ. Virus taxonomy: classification and nomenclature of viruses. Ninth report of the International Committee on Taxonomy of Viruses. London, United Kingdom: Academic Press, 2012:806-820

24. World Health Organization (WHO). Middle East respiratory syndrome coronavirus (MERS-CoV). Fact sheet $\mathrm{N}^{\circ} 401$. June 2015. Available from http://www.who.int/mediacentre/factsheets/ mers-cov/en/\# (Accessed June 8, 2016)

25. De Benedictis P, Marciano S, Scaravelli D, Priori P, Zecchin B, Capua I, Monne I, Cattoli G. Alpha and lineage $\mathrm{C}$ betaCoV infections in Italian bats. Virus Genes 2014; 48(2): 366-371

26. de Groot RJ, Baker SC, Baric RS, Brown CS, Drosten C, Enjuanes L, Fouchier RA, Galiano M, Gorbalenya AE, Memish ZA, Perlman S, Poon LL, Snijder EJ, Stephens GM, Woo PC, Zaki AM, Zambon M, Ziebuhr J. Middle East respiratory syndrome coronavirus (MERS-CoV): announcement of the Coronavirus Study Group. J Virol 2013; 87(14): 7790-7792

27. Reusken CB, Lina PH, Pielaat A, de Vries A, Dam-Deisz C, Adema J, Drexler JF, Drosten C, Kooi EA. Circulation of group 2 coronaviruses in a bat species common to urban areas in Western Europe. Vector Borne Zoonotic Dis 2010; 10(8): 785-791

28. Reusken CB, Raj VS, Koopmans MP, Haagmans BL. Cross host transmission in the emergence of MERS coronavirus. Curr Opin Virol 2016; 16: 55-62

29. Woo PC, Wang M, Lau SK, Xu H, Poon RW, Guo R, Wong BH, Gao K, Tsoi HW, Huang Y, Li KS, Lam CS, Chan KH, Zheng BJ,
Yuen KY. Comparative analysis of twelve genomes of three novel group $2 \mathrm{c}$ and group $2 \mathrm{~d}$ coronaviruses reveals unique group and subgroup features. J Virol 2007; 81(4): 1574-1585

30. Corman VM, Ithete NL, Richards LR, Schoeman MC, Preiser W, Drosten C, Drexler JF. Rooting the phylogenetic tree of Middle East respiratory syndrome coronavirus by characterization of a conspecific virus from an African bat. J Virol 2014; 88(19): 1129711303

31. Ithete NL, Stoffberg S, Corman VM, Cottontail VM, Richards LR, Schoeman MC, Drosten C, Drexler JF, Preiser W. Close relative of human Middle East respiratory syndrome coronavirus in bat, South Africa. Emerg Infect Dis 2013; 19(10): 1697-1699

32. Rambaut A. MERS-coronavirus molecular epidemiology and genetic analysis —origin and evolution. 2014. Available at http:// epidemic.bio.ed.ac.uk/coronavirus_analysis (Accessed June 14, 2016)

33. Corman VM, Jores J, Meyer B, Younan M, Liljander A, Said MY, Gluecks I, Lattwein E, Bosch BJ, Drexler JF, Bornstein S, Drosten C, Müller MA. Antibodies against MERS coronavirus in dromedary camels, Kenya, 1992-2013. Emerg Infect Dis 2014; 20(8): 1319-1322

34. Haagmans BL, Al Dhahiry SH, Reusken CB, Raj VS, Galiano M, Myers R, Godeke GJ, Jonges M, Farag E, Diab A, Ghobashy H, Alhajri F, Al-Thani M, Al-Marri SA, Al Romaihi HE, Al Khal A, Bermingham A, Osterhaus AD, AlHajri MM, Koopmans MP. Middle East respiratory syndrome coronavirus in dromedary camels: an outbreak investigation. Lancet Infect Dis 2014; 14(2): 140-145

35. Perera RA, Wang P, Gomaa MR, El-Shesheny R, Kandeil A, Bagato O, Siu LY, Shehata MM, Kayed AS, Moatasim Y, Li M, Poon LL, Guan Y, Webby RJ, Ali MA, Peiris JS, Kayali G. Seroepidemiology for MERS coronavirus using microneutralisation and pseudoparticle virus neutralisation assays reveal a high prevalence of antibody in dromedary camels in Egypt, June 2013. Euro Surveill 2013; 18(36): 20574

36. World Health Organization (WHO). Latest updates on MERSCoV. Available from http://www.who.int/csr/don/16-may-2016mers-saudi-arabia/en/ (Accessed June 8, 2016)

37. Graham RL, Baric RS. Recombination, reservoirs, and the modular spike: mechanisms of coronavirus cross-species transmission. $\mathrm{J}$ Virol 2010; 84(7): 3134-3146

38. Qian Z, Dominguez SR, Holmes KV. Role of the spike glycoprotein of human Middle East respiratory syndrome coronavirus (MERS-CoV) in virus entry and syncytia formation. PLoS One 2013; 8(10): e76469

39. Raj VS, Mou H, Smits SL, Dekkers DH, Müller MA, Dijkman R, Muth D, Demmers JA, Zaki A, Fouchier RA, Thiel V, Drosten C, Rottier PJ, Osterhaus AD, Bosch BJ, Haagmans BL. Dipeptidyl peptidase 4 is a functional receptor for the emerging human coronavirus-EMC. Nature 2013; 495(7440): 251-254

40. Wang N, Shi X, Jiang L, Zhang S, Wang D, Tong P, Guo D, Fu L, Cui Y, Liu X, Arledge KC, Chen YH, Zhang L, Wang X. Structure of MERS-CoV spike receptor-binding domain complexed with human receptor DPP4. Cell Res 2013; 23(8): 986-993

41. Yang Y, Liu C, Du L, Jiang S, Shi Z, Baric RS, Li F. Two mutations were critical for bat-to-human transmission of Middle East respiratory syndrome coronavirus. J Virol 2015; 89(17): 
9119-9123

42. Modjarrad K. MERS-CoV vaccine candidates in development: The current landscape. Vaccine 2016; 34(26): 2982-2987

43. Chu DK, Oladipo JO, Perera RA, Kuranga SA, Chan SM, Poon LL, Peiris M. Middle East respiratory syndrome coronavirus (MERS-CoV) in dromedary camels in Nigeria, 2015. Euro Surveill 2015; 20(49): 30086

44. Farag EA, Reusken CB, Haagmans BL, Mohran KA, Stalin Raj V, Pas SD, Voermans J, Smits SL, Godeke GJ, Al-Hajri MM, Alhajri FH, Al-Romaihi HE, Ghobashy H, El-Maghraby MM, El-Sayed AM, Al Thani MH, Al-Marri S, Koopmans MP. High proportion of MERS-CoV shedding dromedaries at slaughterhouse with a potential epidemiological link to human cases, Qatar 2014. Infect Ecol Epidemiol 2015; 5(1): 28305

45. Raj VS, Farag EA, Reusken CB, Lamers MM, Pas SD, Voermans J, Smits SL, Osterhaus AD, Al-Mawlawi N, Al-Romaihi HE, AlHajri MM, El-Sayed AM, Mohran KA, Ghobashy H, Alhajri F, Al-Thani M, Al-Marri SA, El-Maghraby MM, Koopmans MP, Haagmans BL. Isolation of MERS coronavirus from a dromedary camel, Qatar, 2014. Emerg Infect Dis 2014; 20(8): 1339-1342

46. Reusken CB, Ababneh M, Raj VS, Meyer B, Eljarah A, Abutarbush S, Godeke GJ, Bestebroer TM, Zutt I, Müller MA, Bosch BJ, Rottier PJ, Osterhaus AD, Drosten C, Haagmans BL, Koopmans MP. Middle East respiratory syndrome coronavirus (MERS-CoV) serology in major livestock species in an affected region in Jordan, June to September 2013. Euro Surveill 2013; 18 (50): 20662

47. Reusken CB, Haagmans BL, Müller MA, Gutierrez C, Godeke GJ, Meyer B, Muth D, Raj VS, Smits-De Vries L, Corman VM, Drexler JF, Smits SL, El Tahir YE, De Sousa R, van Beek J, Nowotny N, van Maanen K, Hidalgo-Hermoso E, Bosch BJ, Rottier P, Osterhaus A, Gortázar-Schmidt C, Drosten C, Koopmans MP. Middle East respiratory syndrome coronavirus neutralising serum antibodies in dromedary camels: a comparative serological study. Lancet Infect Dis 2013; 13(10): 859-866

48. Reusken CB, Farag EA, Jonges M, Godeke GJ, El-Sayed AM, Pas SD, Raj VS, Mohran KA, Moussa HA, Ghobashy H, Alhajri F, Ibrahim AK, Bosch BJ, Pasha SK, Al-Romaihi HE, Al-Thani M, Al-Marri SA, AlHajri MM, Haagmans BL, Koopmans MP. Middle East respiratory syndrome coronavirus (MERS-CoV) RNA and neutralising antibodies in milk collected according to local customs from dromedary camels, Qatar, April 2014. Euro Surveill 2014; 19 (23): 20829

49. Reusken CB, Schilp C, Raj VS, De Bruin E, Kohl RH, Farag EA, Haagmans BL, Al-Romaihi H, Le Grange F, Bosch BJ, Koopmans MP. MERS-CoV infection of alpaca in a region where MERS-CoV is endemic. Emerg Infect Dis 2016; 22(6): 1129-1131

50. Memish ZA, Assiri A, Turkestani A, Yezli S, Al Masri M, Charrel R, Drali T, Gaudart J, Edouard S, Parola P, Gautret P. Mass gathering and globalization of respiratory pathogens during the 2013 Hajj. Clin Microbiol Infect 2015; 21(6): 571.e1-571.e8

51. Memish ZA, Assiri A, Almasri M, Alhakeem RF, Turkestani A, Al Rabeeah AA, Al-Tawfiq JA, Alzahrani A, Azhar E, Makhdoom HQ, Hajomar WH, Al-Shangiti AM, Yezli S. Prevalence of MERS$\mathrm{CoV}$ nasal carriage and compliance with the Saudi health recommendations among pilgrims attending the 2013 Hajj. J Infect Dis 2014; 210(7): 1067-1072

52. Gautret P, Charrel R, Benkouiten S, Belhouchat K, Nougairede A,
Drali T, Salez N, Memish ZA, Al Masri M, Lagier JC, Million M, Raoult D, Brouqui P, Parola P. Lack of MERS coronavirus but prevalence of influenza virus in French pilgrims after 2013 Hajj. Emerg Infect Dis 2014; 20(4): 728-730

53. Barasheed O, Rashid H, Alfelali M, Tashani M, Azeem M, Bokhary H, Kalantan N, Samkari J, Heron L, Kok J, Taylor J, El Bashir H, Memish ZA, Haworth E, Holmes EC, Dwyer DE, Asghar A, Booy R; Hajj Research Team. Viral respiratory infections among Hajj pilgrims in 2013. Virol Sin 2014; 29(6): 364-371

54. Alraddadi BM, Watson JT, Almarashi A, Abedi GR, Turkistani A, Sadran M, Housa A, Almazroa MA, Alraihan N, Banjar A, Albalawi E, Alhindi H, Choudhry AJ, Meiman JG, Paczkowski M, Curns A, Mounts A, Feikin DR, Marano N, Swerdlow DL, Gerber SI, Hajjeh R, Madani TA. Risk factors for primary Middle East respiratory syndrome coronavirus illness in humans, Saudi Arabia, 2014. Emerg Infect Dis 2016; 22(1): 49-55

55. Reusken CB, Farag EA, Haagmans BL, Mohran KA, Godeke GJ 5th, Raj S, Alhajri F, Al-Marri SA, Al-Romaihi HE, Al-Thani M, Bosch BJ, van der Eijk AA, El-Sayed AM, Ibrahim AK, AlMolawi N, Müller MA, Pasha SK, Drosten C, AlHajri MM, Koopmans MP. Occupational exposure to dromedaries and risk for MERS-CoV infection, Qatar, 2013-2014. Emerg Infect Dis 2015; 21(8): 1422-1425

56. Memish ZA, Cotten M, Meyer B, Watson SJ, Alsahafi AJ, Al Rabeeah AA, Corman VM, Sieberg A, Makhdoom HQ, Assiri A, Al Masri M, Aldabbagh S, Bosch BJ, Beer M, Müller MA, Kellam $P$, Drosten C. Human infection with MERS coronavirus after exposure to infected camels, Saudi Arabia, 2013. Emerg Infect Dis 2014; 20(6): 1012-1015

57. Azhar EI, El-Kafrawy SA, Farraj SA, Hassan AM, Al-Saeed MS, Hashem AM, Madani TA. Evidence for camel-to-human transmission of MERS coronavirus. N Engl J Med 2014; 370(26): 24992505

58. World Health Organization (WHO). Laboratory testing for Middle East respiratory syndrome coronavirus: interim guidance. 2015. Available from http://www.who.int/csr/disease/coronavirus_infections/mers-laboratory-testing/en/ (Accessed June 14, 2016)

59. Corman VM, Müller MA, Costabel U, Timm J, Binger T, Meyer B, Kreher P, Lattwein E, Eschbach-Bludau M, Nitsche A, Bleicker T, Landt O, Schweiger B, Drexler JF, Osterhaus AD, Haagmans BL, Dittmer U, Bonin F, Wolff T, Drosten C. Assays for laboratory confirmation of novel human coronavirus (hCoV-EMC) infections. Euro Surveill 2012; 17(49): 1

60. Muth D, Corman VM, Meyer B, Assiri A, Al-Masri M, Farah M, Steinhagen K, Lattwein E, Al-Tawfiq JA, Albarrak A, Müller MA, Drosten C, Memish ZA. Infectious Middle East respiratory syndrome coronavirus excretion and serotype variability based on live virus isolates from patients in Saudi Arabia. J Clin Microbiol 2015; 53(9): 2951-2955

61. Meyer B, Drosten C, Müller MA. Serological assays for emerging coronaviruses: challenges and pitfalls. Virus Res 2014; 194: 175183

62. Reusken CB, Messadi L, Feyisa A, Ularamu H, Godeke GJ, Danmarwa A, Dawo F, Jemli M, Melaku S, Shamaki D, Woma Y, Wungak Y, Gebremedhin EZ, Zutt I, Bosch BJ, Haagmans BL, Koopmans MP. Geographic distribution of MERS coronavirus among dromedary camels, Africa. Emerg Infect Dis 2014; 20(8): 


\section{$1370-1374$}

63. Liljander A, Meyer B, Jores J, Müller MA, Lattwein E, Njeru I, Bett B, Drosten C, Corman VM. MERS-CoV antibodies in humans, Africa, 2013-2014. Emerg Infect Dis 2016; 22(6): 10861089

64. Müller MA, Meyer B, Corman VM, Al-Masri M, Turkestani A, Ritz D, Sieberg A, Aldabbagh S, Bosch BJ, Lattwein E, Alhakeem RF, Assiri AM, Albarrak AM, Al-Shangiti AM, Al-Tawfiq JA, Wikramaratna P, Alrabeeah AA, Drosten C, Memish ZA. Presence of Middle East respiratory syndrome coronavirus antibodies in Saudi Arabia: a nationwide, cross-sectional, serological study. Lancet Infect Dis 2015; 15(5): 559-564

65. Butt TS, Koutlakis-Barron I, AlJumaah S, AlThawadi S, AlMofada S. Infection control and prevention practices implemented to reduce transmission risk of Middle East respiratory syndrome-coronavirus in a tertiary care institution in Saudi Arabia. Am J Infect Control 2016; 44(5): 605-611

66. Hastings DL, Tokars JI, Abdel Aziz IZ, Alkhaldi KZ, Bensadek AT, Alraddadi BM, Jokhdar H, Jernigan JA, Garout MA, Tomczyk SM, Oboho IK, Geller AI, Arinaminpathy N, Swerdlow DL, Madani TA. Outbreak of Middle East respiratory syndrome at tertiary care hospital, Jeddah, Saudi Arabia, 2014. Emerg Infect Dis 2016; 22(5): 794-801

67. Nishiura H, Endo A, Saitoh M, Kinoshita R, Ueno R, Nakaoka S, Miyamatsu Y, Dong Y, Chowell G, Mizumoto K. Identifying determinants of heterogeneous transmission dynamics of the Middle East respiratory syndrome (MERS) outbreak in the Republic of Korea, 2015: a retrospective epidemiological analysis. BMJ Open 2016; 6(2): e009936

68. Bermingham A, Chand MA, Brown CS, Aarons E, Tong C, Langrish C, Hoschler K, Brown K, Galiano M, Myers R, Pebody RG, Green HK, Boddington NL, Gopal R, Price N, Newsholme W, Drosten C, Fouchier RA, Zambon M. Severe respiratory illness caused by a novel coronavirus, in a patient transferred to the United Kingdom from the Middle East, September 2012. Euro Surveill 2012; 17(40): 20290

69. Breakwell L, Pringle K, Chea N, Allen D, Allen S, Richards S, Pantones P, Sandoval M, Liu L, Vernon M, Conover C, Chugh R, DeMaria A, Burns R, Smole S, Gerber SI, Cohen NJ, Kuhar D, Haynes LM, Schneider E, Kumar A, Kapoor M, Madrigal M, Swerdlow DL, Feikin DR. Lack of transmission among close contacts of patient with case of middle east respiratory syndrome imported into the United States, 2014. Emerg Infect Dis 2015; 21 (7): $1128-1134$

70. Kraaij-Dirkzwager M, Timen A, Dirksen K, Gelinck L, Leyten E, Groeneveld P, Jansen C, Jonges M, Raj S, Thurkow I, van Gageldonk-Lafeber R, van der Eijk A, Koopmans M; MERS-CoV Outbreak Investigation Team of the Netherlands. Middle East respiratory syndrome coronavirus (MERS-CoV) infections in two returning travellers in the Netherlands, May 2014. Euro Surveill 2014; 19(21): 20817

71. Wiboonchutikul S, Manosuthi W, Likanonsakul S, Sangsajja C, Kongsanan P, Nitiyanontakij R, Thientong V, Lerdsamran H, Puthavathana P. Lack of transmission among healthcare workers in contact with a case of Middle East respiratory syndrome coronavirus infection in Thailand. Antimicrob Resist Infect Control 2016; 5(1): 21
72. Wang Y, Liu D, Shi W, Lu R, Wang W, Zhao Y, Deng Y, Zhou W, Ren H, Wu J, Wang Y, Wu G, Gao GF, Tan W. Origin and possible genetic recombination of the Middle East respiratory syndrome coronavirus from the first imported case in China: phylogenetics and coalescence analysis. MBio 2015; 6(5): e01280-e15

73. Assiri AM, Midgley CM, Abedi GR, Saeed AB, Almasri MM, Lu X, Al-Abdely HM, Abdalla O, Mohammed M, Algarni HS, Alhakeem RF, Sakthivel SK, Nooh R, Alshayab Z, Alessa M, Srinivasamoorthy G, AlQahtani SY, Kheyami A, HajOmar WH, Banaser TM, Esmaeel A, Hall AJ, Curns AT, Tamin A, Alsharef AA, Erdman D, Watson JT, Gerber SI. Epidemiology of a novel recombinant MERS-CoV in humans in Saudi Arabia. J Infect Dis 2016; 214(5): 712-721

74. Wernery U, Lau SK, Woo PC. Genomics and zoonotic infections: Middle East respiratory syndrome. Rev Sci Tech 2016; 35(1): 191202

75. Chu DK, Poon LL, Gomaa MM, Shehata MM, Perera RA, Abu Zeid D, El Rifay AS, Siu LY, Guan Y, Webby RJ, Ali MA, Peiris M, Kayali G. MERS coronaviruses in dromedary camels, Egypt. Emerg Infect Dis 2014; 20(6): 1049-1053

76. Smits SL, Raj VS, Pas SD, Reusken CB, Mohran K, Farag EA, AlRomaihi HE, AlHajri MM, Haagmans BL, Koopmans MP. Reliable typing of MERS-CoV variants with a small genome fragment. J Clin Virol 2015; 64: 83-87

77. Kandeil A, Shehata MM, El Shesheny R, Gomaa MR, Ali MA, Kayali G. Complete genome sequence of Middle East respiratory syndrome coronavirus isolated from a dromedary camel in Egypt. Genome Announc 2016; 4(2): e00309-e00316

78. Dudas G, Rambaut A. MERS-CoV recombination: implications about the reservoir and potential for adaptation. doi: http://dx.doi. org/10.1101/020834. 2015. Available from: http://biorxiv.org/ content/early/2015/12/23/020834 (Accessed June 15, 2016)

79. McRoy WC, Baric RS. Amino acid substitutions in the S2 subunit of mouse hepatitis virus variant V51 encode determinants of host range expansion. J Virol 2008; 82(3): 1414-1424

80. Sheahan T, Rockx B, Donaldson E, Sims A, Pickles R, Corti D, Baric R. Mechanisms of zoonotic severe acute respiratory syndrome coronavirus host range expansion in human airway epithelium. J Virol 2008; 82(5): 2274-2285

81. Durai P, Batool M, Shah M, Choi S. Middle East respiratory syndrome coronavirus: transmission, virology and therapeutic targeting to aid in outbreak control. Exp Mol Med 2015; 47(8): e181

82. Kim Y, Cheon S, Min CK, Sohn KM, Kang YJ, Cha YJ, Kang JI, Han SK, Ha NY, Kim G, Aigerim A, Shin HM, Choi MS, Kim S, Cho HS, Kim YS, Cho NH. Spread of mutant Middle East respiratory syndrome coronavirus with reduced affinity to human CD26 during the South Korean outbreak. MBio 2016; 7(2): e00019-e16

83. Forni D, Filippi G, Cagliani R, De Gioia L, Pozzoli U, Al-Daghri N, Clerici M, Sironi M. The heptad repeat region is a major selection target in MERS-CoV and related coronaviruses. Sci Rep 2015; 5: 14480

84. Ho BL, Cheng SC, Shi L, Wang TY, Ho KI, Chou CY. Critical Assessment of the important residues involved in the dimerization and catalysis of MERS coronavirus main protease. PLoS One 2015; 10(12): e0144865 
85. Omrani AS, Saad MM, Baig K, Bahloul A, Abdul-Matin M, Alaidaroos AY, Almakhlafi GA, Albarrak MM, Memish ZA, Albarrak AM. Ribavirin and interferon alfa-2a for severe Middle East respiratory syndrome coronavirus infection: a retrospective cohort study. Lancet Infect Dis 2014; 14(11): 1090-1095

86. Spanakis N, Tsiodras S, Haagmans BL, Raj VS, Pontikis K, Koutsoukou A, Koulouris NG, Osterhaus AD, Koopmans MP, Tsakris A. Virological and serological analysis of a recent Middle East respiratory syndrome coronavirus infection case on a triple combination antiviral regimen. Int J Antimicrob Agents 2014; 44 (6): $528-532$

87. Falzarano D, de Wit E, Rasmussen AL, Feldmann F, Okumura A, Scott DP, Brining D, Bushmaker T, Martellaro C, Baseler L, Benecke AG, Katze MG, Munster VJ, Feldmann H. Treatment with interferon- $\alpha 2 b$ and ribavirin improves outcome in MERSCoV-infected rhesus macaques. Nat Med 2013; 19(10): 13131317

88. Hart BJ, Dyall J, Postnikova E, Zhou H, Kindrachuk J, Johnson RF, Olinger GG Jr, Frieman MB, Holbrook MR, Jahrling PB, Hensley L. Interferon- $\beta$ and mycophenolic acid are potent inhibitors of Middle East respiratory syndrome coronavirus in cell-based assays. J Gen Virol 2014; 95(Pt 3): 571-577

89. Rossignol JF. Nitazoxanide, a new drug candidate for the treatment of Middle East respiratory syndrome coronavirus. J Infect Public Health 2016; 9(3): 227-230

90. Lu L, Liu Q, Zhu Y, Chan KH, Qin L, Li Y, Wang Q, Chan JF, Du L, Yu F, Ma C, Ye S, Yuen KY, Zhang R, Jiang S. Structure-based discovery of Middle East respiratory syndrome coronavirus fusion inhibitor. Nat Commun 2014; 5: 3067

91. Bosch BJ, Martina BE, Van Der Zee R, Lepault J, Haijema BJ, Versluis C, Heck AJ, De Groot R, Osterhaus AD, Rottier PJ. Severe acute respiratory syndrome coronavirus (SARS-CoV) infection inhibition using spike protein heptad repeat-derived peptides. Proc Natl Acad Sci USA 2004; 101(22): 8455-8460

92. Liu S, Xiao G, Chen Y, He Y, Niu J, Escalante CR, Xiong H, Farmar J, Debnath AK, Tien P, Jiang S. Interaction between heptad repeat 1 and 2 regions in spike protein of SARS-associated coronavirus: implications for virus fusogenic mechanism and identification of fusion inhibitors. Lancet 2004; 363(9413): 938947

93. Channappanavar R, Lu L, Xia S, Du L, Meyerholz DK, Perlman S, Jiang S. Protective effect of intranasal regimens containing peptidic Middle East respiratory syndrome coronavirus fusion inhibitor against MERS-CoV infection. J Infect Dis 2015; 212(12): 1894-1903

94. Lei J, Mesters JR, Drosten C, Anemüller S, Ma Q, Hilgenfeld R. Crystal structure of the papain-like protease of MERS coronavirus reveals unusual, potentially druggable active-site features. Antiviral Res 2014; 109: 72-82

95. Corman VM, Albarrak AM, Omrani AS, Albarrak MM, Farah ME, Almasri M, Muth D, Sieberg A, Meyer B, Assiri AM, Binger T, SteinhagenK, LattweinE, Al-TawfiqJ, MüllerMA, DrostenC, Memish ZA. Viral shedding and antibody response in 37 patients with MERS-coronavirus infection. Clin Infect Dis 2015; 62(4): 477-483

96. Muth D, Corman VM, Meyer B, Assiri A, Al-Masri M, Farah M, Steinhagen K, Lattwein E, Al-Tawfiq JA, Albarrak A, Müller MA,
Drosten C, Memish ZA. Infectious Middle East respiratory syndrome coronavirus excretion and serotype variability based on live virus isolates from patients in Saudi Arabia. J Clin Microbiol 2015; 53(9): 2951-2955

97. Du L, Kou Z, Ma C, Tao X, Wang L, Zhao G, Chen Y, Yu F, Tseng CT, Zhou Y, Jiang S. A truncated receptor-binding domain of MERS-CoV spike protein potently inhibits MERS-CoV infection and induces strong neutralizing antibody responses: implication for developing therapeutics and vaccines. PLoS One 2013; 8(12): e81587

98. Kumar V, Jung YS, Liang PH. Anti-SARS coronavirus agents: a patent review (2008-present). Expert Opin Ther Pat 2013; 23(10): 1337-1348

99. Ma C, Li Y, Wang L, Zhao G, Tao X, Tseng CT, Zhou Y, Du L, Jiang $S$. Intranasal vaccination with recombinant receptor-binding domain of MERS-CoV spike protein induces much stronger local mucosal immune responses than subcutaneous immunization: Implication for designing novel mucosal MERS vaccines. Vaccine 2014; 32(18): 2100-2108

100. Wang L, Shi W, Joyce MG, Modjarrad K, Zhang Y, Leung K, Lees CR, Zhou T, Yassine HM, Kanekiyo M, Yang ZY, Chen X, Becker MM, Freeman M, Vogel L, Johnson JC, Olinger G, Todd JP, Bagci U, Solomon J, Mollura DJ, Hensley L, Jahrling P, Denison MR, Rao SS, Subbarao K, Kwong PD, Mascola JR, Kong WP, Graham BS. Evaluation of candidate vaccine approaches for MERS-CoV. Nat Commun 2015; 6: 7712

101. Zhang N, Tang J, Lu L, Jiang S, Du L. Receptor-binding domainbased subunit vaccines against MERS-CoV. Virus Res 2015; 202 : 151-159

102. Lan J, Yao Y, Deng Y, Chen H, Lu G, Wang W, Bao L, Deng W, Wei Q, Gao GF, Qin C, Tan W. Recombinant receptor binding domain protein induces partial protective immunity in rhesus macaques against Middle East respiratory syndrome coronavirus challenge. EBioMedicine 2015; 2(10): 1438-1446

103. Coleman CM, Liu YV, Mu H, Taylor JK, Massare M, Flyer DC, Glenn GM, Smith GE, Frieman MB. Purified coronavirus spike protein nanoparticles induce coronavirus neutralizing antibodies in mice. Vaccine 2014; 32(26): 3169-3174

104. Song F, Fux R, Provacia LB, Volz A, Eickmann M, Becker S, Osterhaus AD, Haagmans BL, Sutter G. Middle East respiratory syndrome coronavirus spike protein delivered by modified vaccinia virus Ankara efficiently induces virus-neutralizing antibodies. J Virol 2013; 87(21): 11950-11954

105. Volz A, Kupke A, Song F, Jany S, Fux R, Shams-Eldin H, Schmidt J, Becker C, Eickmann M, Becker S, Sutter G. Protective efficacy of recombinant modified vaccinia virus Ankara delivering Middle East respiratory syndrome coronavirus spike glycoprotein. J Virol 2015; 89(16): 8651-8656

106. Guo X, Deng Y, Chen H, Lan J, Wang W, Zou X, Hung T, Lu Z, Tan W. Systemic and mucosal immunity in mice elicited by a single immunization with human adenovirus type 5 or 41 vectorbased vaccines carrying the spike protein of Middle East respiratory syndrome coronavirus. Immunology 2015; 145(4): 476-484

107. Kim E, Okada K, Kenniston T, Raj VS, AlHajri MM, Farag EA, AlHajri F, Osterhaus AD, Haagmans BL, Gambotto A. Immunogenicity of an adenoviral-based Middle East respiratory syndrome 
coronavirus vaccine in $\mathrm{BALB} / \mathrm{c}$ mice. Vaccine 2014; 32(45): $5975-5982$

108. Inovio. GLS-5300 SynCon ${ }^{\circledR}$ immunotherapy targeting Middle East Respiratory Syndrome. 2016. Available from http://www. inovio.com/products/infectious-disease-vaccines/mers/ (Accessed June 20, 2016)

109. Muthumani K, Falzarano D, Reuschel EL, Tingey C, Flingai S, Villarreal DO, Wise M, Patel A, Izmirly A, Aljuaid A, Seliga AM, Soule G, Morrow M, Kraynyak KA, Khan AS, Scott DP, Feldmann F, LaCasse R, Meade-White K, Okumura A, Ugen KE, Sardesai NY, Kim JJ, Kobinger G, Feldmann H, Weiner DB. A synthetic consensus anti-spike protein DNA vaccine induces protective immunity against Middle East respiratory syndrome coronavirus in nonhuman primates. Sci Transl Med 2015; 7(301): $301 \mathrm{ra} 132$

110. Corti D, Zhao J, Pedotti M, Simonelli L, Agnihothram S, Fett C, Fernandez-Rodriguez B, Foglierini M, Agatic G, Vanzetta F, Gopal R, Langrish CJ, Barrett NA, Sallusto F, Baric RS, Varani L, Zambon M, Perlman S, Lanzavecchia A. Prophylactic and postexposure efficacy of a potent human monoclonal antibody against MERS coronavirus. Proc Natl Acad Sci USA 2015; 112 (33): 10473-10478
111. Jiang L, Wang N, Zuo T, Shi X, Poon KM, Wu Y, Gao F, Li D, Wang R, Guo J, Fu L, Yuen KY, Zheng BJ, Wang X, Zhang L. Potent neutralization of MERS-CoV by human neutralizing monoclonal antibodies to the viral spike glycoprotein. Sci Transl Med 2014; 6(234): 234ra59

112. Pascal KE, Coleman CM, Mujica AO, Kamat V, Badithe A, Fairhurst J, Hunt C, Strein J, Berrebi A, Sisk JM, Matthews KL, Babb R, Chen G, Lai KM, Huang TT, Olson W, Yancopoulos GD, Stahl N, Frieman MB, Kyratsous CA. Pre- and postexposure efficacy of fully human antibodies against Spike protein in a novel humanized mouse model of MERS-CoV infection. Proc Natl Acad Sci USA 2015; 112(28): 8738-8743

113. Ying T, Du L, Ju TW, Prabakaran P, Lau CC, Lu L, Liu Q, Wang L, Feng Y, Wang Y, Zheng BJ, Yuen KY, Jiang S, Dimitrov DS. Exceptionally potent neutralization of Middle East respiratory syndrome coronavirus by human monoclonal antibodies. J Virol 2014; 88(14): 7796-7805

114. Ying T, Prabakaran P, Du L, Shi W, Feng Y, Wang Y, Wang L, Li W, Jiang S, Dimitrov DS, Zhou T. Junctional and allele-specific residues are critical for MERS-CoV neutralization by an exceptionally potent germline-like antibody. Nat Commun 2015; 6: 8223 